Doi: $\underline{\mathrm{dx} . \text { doi.org/10.17921/2525-5320.2016.225-227 }}$

\title{
O PROCESSO DO EXAME SUPLETIVO ONLINE NO ESTADO DE MATO GROSSO
}

Maria Aparecida dos Reis* - UNOPAR

Palavras-chave: Educação. Tecnologia. Supletivo Online.

\section{INTRODUÇÃO}

Vivemos em uma era caracterizada por um processo de mudanças cada vez mais abrangente e acelerado, do qual a tecnologia é a força motriz. Nesse sentido, a Secretaria de Estado de Educação do Estado de Mato Grosso (SEDUC), pensando em acompanhar essas mudanças, em 2011 implantou o Exame Supletivo Online.

O processo possibilita desde o agendamento das provas até a realização das mesmas via WEB, interligando assim, a oferta do exame nos 22 Centros de Educação de Jovens e Adultos - CEJA do estado. O exame é pré-agendado pelo candidato, no qual, ele se inscreve por área de conhecimento, através do site da SEDUC, www.seduc.mt.gov.br. A prova é feita presencial em um dos CEJA selecionado pelo aluno.

O grande diferencial é que o sistema fica disponível o ano todo, o aluno pode fazer na data que lhe for conveniente. Portanto, o agendamento só é feito atendendo um período da inscrição até a realização da prova de dois meses, para que o aluno não perca de vista a data da prova.

Proporcionar aos jovens e adultos a regularização funcional e/ou escolar, na perspectiva de exercer sua cidadania, contribuir para a inserção no mercado de trabalho e dar continuidade aos estudos. O processo visa também ofertar maior comodidade ao candidato, economia de tempo e espaço e agilidade e transparência na sua realização.

\section{MATERIAL E MÉTODOS}

A escolha pela metodologia qualitativa se deu pela necessidade de compreender o indivíduo dentro do seu contexto social, conforme Triviños (1987). Nesse sentido, o

\footnotetext{
*E-mail:mariareismt@hotmail.com
} 
referido projeto surgiu considerando o contexto geográfico do estado de Mato Grosso, pela grande extensão territorial. Assim, surgiu a necessidade de implantar um Sistema Online, na perspectiva de acabar com os limites espaciais e temporais, que impediam alguns sujeitos de frequentarem a escola regularmente.

A inscrição e agendamento são feitos totalmente online. Uma das exigências é que o aluno tenha um e-mail ativo, para que a SEDUC encaminhe sua senha de acesso. Após a confirmação da inscrição, o aluno acessa o sistema e encontra todo o material de estudo disponível, de acordo com a sua inscrição.

Assim, não há gastos exorbitantes, pois os materiais necessários são os que já existem no CEJA, o laboratório de informática, com internet banda larga e técnicos para atender os alunos no dia da realização da prova.

\section{RESULTADOS E DISCUSSÃO}

De acordo com Arroyo (2005), o direito à educação de jovens e adultos deve ir além de oportunizar o direito a escolarização. É necessário um novo olhar para esses sujeitos, que por algum motivo foi privado do direito de estudar na idade certa.

Nesta perspectiva, a SEDUC cumpre com o que está descrito no parecer CNE/CEB 11/2000, que cita as três funções da EJA: reparadora, equalizadora e permanente/qualificadora. Assim, ao proporcionar o Exame Supletivo Online, irá reparar o direito negado de acesso à escolarização, equalizar, incluir esses sujeitos no sistema educacional, qualificadora, que é universalizar e promover a igualdade de cidadania a todos.

Os resultados apontados pela SEDUC mostram que no ano de 2015 foram 70.000 inscrições efetivadas e 53.000 pessoas fizeram as provas, com conclusão parcial ou total. Vale ressaltar que o Exame Supletivo Online não atende só pessoas do estado de Mato Grosso, atende os estados vizinhos, como Goiás e Mato Grosso do Sul.

\section{CONCLUSÃO}

Ao analisar cinco anos de implantação do projeto, constamos que, formar cidadãos preparados para o mundo contemporâneo é um grande desafio, para quem dimensiona e promove a educação. Assim sendo, concluímos que o desafio foi enorme, fomos arrojados, pois o Exame Supletivo Online, neste modelo, é o único no 
Brasil. Vale a pena qualquer esforço coletivo, quando um aluno chega para pegar sua certificação dizendo que irá ingressar na Faculdade, cumprimos nosso papel.

\section{REFERÊNCIAS}

ARROYO, M.G. Educação de jovens e adultos: um campo de direitos e de responsabilidade pública. In: SOARES, L.; GIOVANETTI, M.A.; GOMES, N.L. (Org.). Diálogos na Educação de Jovens e Adultos. Belo Horizonte: Autêntica, 2005. p.19-50.

COSCARELLI, C.V.; RIBEIRO, A.E. Letramento digital: aspectos sociais e possibilidades pedagógicas. Belo Horizonte: Autentica, 2007.

TRIVIÑOS, A.N.S. Introdução à pesquisa em ciências sociais: a pesquisa qualitativa em educação. São Paulo: Atlas, 